\title{
Management of colonic volvulus. Experience in 75 patients
}

\author{
C. Mulas, M. Bruna, J. García-Armengol and J. V. Roig \\ Department of General Surgery and Digestive Diseases. Consorcio Hospital General Universitario de Valencia. Spain
}

\begin{abstract}
Background: the diagnostic and therapeutic management of colonic volvulus remains nowadays controversial. The election of the type of surgery, its timing, or the use of non-operative decompression must be based on the experience of a multidisciplinary team, the clinical condition of the patient, and the type of volvulus.

Objectives: the purpose of this study is to review our experience and results in the treatment of patients with colonic volvulus.

Material and methods: we performed a retrospective study of patients diagnosed of colonic volvulus between January 1990 and September 2008 in our institution.

Results: we included a total of 75 patients with a mean age of 72.7 years and, in most cases, with associated comorbidities and constipation. The most frequently involved segment was sigmoid colon (85.3\%). A rectal tube insertion was used as the only therapeutic measure in 17 patients $(22.4 \%)$, colonoscopic decompression in 17 (22.4\%), and surgery in 41 patients (55.2\%). Intestinal resection with primary anastomosis was the most common surgical option. Postoperative morbidity was $43 \%$, being wound infections the most frequent complication. In the group of non-surgical treatment morbidity was $26.4 \%$, albeit with a higher and early rate of recurrences.

Conclusions: treatment of colonic volvulus present important morbidity and mortality rates, and its treatment must be individualized. Resective surgery with primary anastomosis in clinically stable patients is the most appropriate therapeutic option, offering the lower recurrence rates.
\end{abstract}

Key words: Colonic volvulus. Intestinal obstruction. Endoscopic decompression. Surgical treatment.

Mulas C, Bruna M, García-Armengol J, Roig JV. Management of colonic volvulus. Experience in 75 patients. Rev Esp Enferm Dig 2010; 102: 239-248.

Received: 27-08-09.

Accepted: 17-12-09.

Correspondence: Claudia Mulas Fernández. Servicio de Cirugía General y del Aparato Digestivo. Consorcio Hospital General Universitario de Valencia. Avda. Tres Cruces, s/n. 46014 Valencia.e-mail: claudiamulas@comv.es

\section{INTRODUCTION}

Colonic volvulus is defined as the torsion of the large intestine around its mesenteric axis, which leads to an acute colonic obstruction. It represents in our medium between 5-10\% of all cases of low intestinal obstruction (1).

Early and correct diagnosis of this entity, characteristic of the elderly, is essential to achieve an appropriate treatment aimed at correcting the electrolyte and nutritional changes that occur and restore the intestinal transit, solving the mechanical problem caused by the volvulus $(2,3)$.

Currently, there is disagreement in the treatment of patients with colonic volvulus. On one hand, it seems evident that urgent resective surgery is the appropriate treatment for those who present an acute abdomen, intestinal perforation or ischemic necrosis of the intestinal mucosa (2-8). On the other hand, the initial management of patients clinically stable and in good general condition following endoscopic decompression is accepted in many institutions as a first therapeutic option. Controversy appears at the time of deciding the type of definitive treatment in each case as well as the strategy and most appropriate surgical technique $(4,9)$.

There is little national bibliography and short series on this subject $(10,11)$, so we have set as objectives of this study to review our experience and results in the treatment of patients with colonic volvulus.

\section{MATERIAL AND METHODS}

We conducted a retrospective, descriptive study of patients diagnosed and treated for colonic volvulus in our center from January 1990 to September 2008 compiling a database.

Through detailed review of medical records of patients, epidemiological parameters have been recorded, as well as clinic presentation, physical examination and 
the different diagnostic-therapeutic methods employed in their management, including diagnostic imaging, ASA score, physiological Possum score, intraoperative findings and surgical technique or endoscopic procedure used in each case. We have also analyzed the clinical course of the episode, morbidity and mortality associated to each technique, its clinical effectiveness and recurrence rates.

Statistical analysis was performed using the SPSS* 15.0 version for Windows* (SPSS Inc., Chicago IL, USA) software package. We used chi-square test and Fisher exact test as appropriate for statistical comparison analysis. Mean and standard deviation were used as measures of central tendency and dispersion for sampling variables with a normal distribution. For those who do not follow a normal distribution, median and range were used. Significance was defined as $p \leq 0.05$.

\section{RESULTS}

A total of 75 patients with a mean age (SD) of 72.7 (16) years were included. Their clinical characteristics are described in table I.

Table I. Clinical data

\begin{tabular}{|c|c|c|c|}
\hline & $n(\%)$ & & $n(\%)$ \\
\hline Gender & & Symptoms and exploration & \\
\hline Men & $43(56.6)$ & Vomits & $33(44)$ \\
\hline Women & $32(42.7)$ & Abdominal distension & $73(97.3)$ \\
\hline Co-morbidity & & Colic pain & $66(88)$ \\
\hline Diabetes & $15(19.7)$ & Continuous pain & $7(9.3)$ \\
\hline COPD & $9(11.8)$ & Peritonism & $5(6.6)$ \\
\hline Cardiac & $28(37.3)$ & ASA Score $(n=73)$ & \\
\hline Neurological & $26(35.5)$ & | & $2(2.7)$ \\
\hline Psiquiatric & $21(28.9)$ & $\|$ & $19(24)$ \\
\hline Previous abdominal surgery & $18(23.7)$ & || $\mid$ & $33(46.7)$ \\
\hline Bowel habits $(n=71)$ & & IV & $14(20)$ \\
\hline Normal & $6(8.4)$ & Mean P-Possum value (SD) & $24.7(9)$ \\
\hline Constipation & $60(84.5)$ & & \\
\hline Diarrhea & $5(7.1)$ & & \\
\hline
\end{tabular}

COPD: chronic pulmonary obstructive disease; SD: standard deviation.

Sigmoid volvulus was the most frequently involved segment, being present in 64 patients $(85.3 \%)$. Much less common was cecal volvulus, present in 10 patients $(13.3 \%)$, and transverse colon volvulus in only 1 patient.

Clinical presentation was variable although most of the patients presented intestinal obstructive symptoms, with a median (range) time evolution of 3 (0-30) days and a median (range) duration of constipation of $2(0-10)$ days.

Among diagnostic tests, plain radiographs of the abdomen were obtained in 72 patients $(96 \%)$, barium enema was used in 27 (36\%), abdominal computed tomography in 8 patients and endoscopy in 43 (57.3\%).

All patients were treated medically by nil per mouth, intravenous fluid therapy and analgesia. The procedures used specifically in the management of the colonic volvulus were: rectal tube placement, colonoscopic decompression and surgery. Figure 1 shows a diagram of the different procedures used and the evolution of our patients. Nine of the 41 patients treated surgically had a rectal tube placed before surgery and 7 underwent an endoscopy before surgery. All patients with cecal volvulus had surgery except one, in who, because of his bad general condition, was decided to try an endoscopic decompression, dying the patient of multiple organ failure.

Emergency surgery was performed in 20 out of the 41 patients (48.8\%), deferred but during the same admission after decompression in $17(41.4 \%)$, and programmed in a different admission of the volvulus episode in 4 cases $(9.8 \%)$, with a median (range) of days from diagnosis to surgery of 4.5 (0-170). There were no significant differences regarding ASA and Possum scores between these groups of patients (Table II). Table III shows the comparative results in terms of morbidity and mortality between urgent and deferred surgery.

Resective surgery was the most common surgical option. We found significant differences between patients undergoing emergency surgery and deferred surgery (95.2 vs. 70\%; $\mathrm{p}=0.036$ ). However, no significant differences were found when comparing the type of surgery performed (resection with primary anastomosis $v s$. Hartmann's procedure). Endoscopic decompression allowed differing surgery and to improve patient's general condition in 4 of the 7 cases where it was used prior to surgery.

Mechanical colonic cleansing was done before surgery in 15 patients (36.5\%), but intraoperative colonic lavage was never used. During surgery, ischemic changes were found in 6 patients $(7.9 \%$ of the total and $14.6 \%$ of those operated). This incidence was higher in patients who underwent emergent surgery ( 25 vs. $4.8 \% ; \mathrm{p}=0.072$ ).

There were complications in 18 of the 41 operated patients $(43.9 \%)$, shown in table III. There was no statistically significant differences in morbidity of resected patients $(14 / 34 ; 41.1 \%)$ versus unresected patients $(4 / 7$; $57.1 \%$ ); $\mathrm{p}=0.21$. Hartmann's procedure (intestinal resection and derivative colostomy) was associated with a postoperative morbidity of $50 \%(8 / 16)$, whereas in patients with primary anastomosis it was of $33.3 \%(6 / 18$; p $=0.17)$. The mean duration of hospital stay (SD) was 16.2 (10) days, and during the follow-up a recurrence was presented in 2 patients (6.2\%), 6 and 10 years after surgery.

A total of $34(45.3 \%)$ patients were non-surgically treated, and complications occurred in $9(26.4 \%)$ of them (Table IV). The co-morbidity associated to this group was higher than in the surgically treated group, showing almost $40 \%$ of these patients association of cardiorespiratory and systemic diseases compared to $9.5 \%$ in the surgical group, $\mathrm{p}=0.016$. The mean duration of hospital stay (SD) of this group was 8.1 (8) days. During follow-up, 


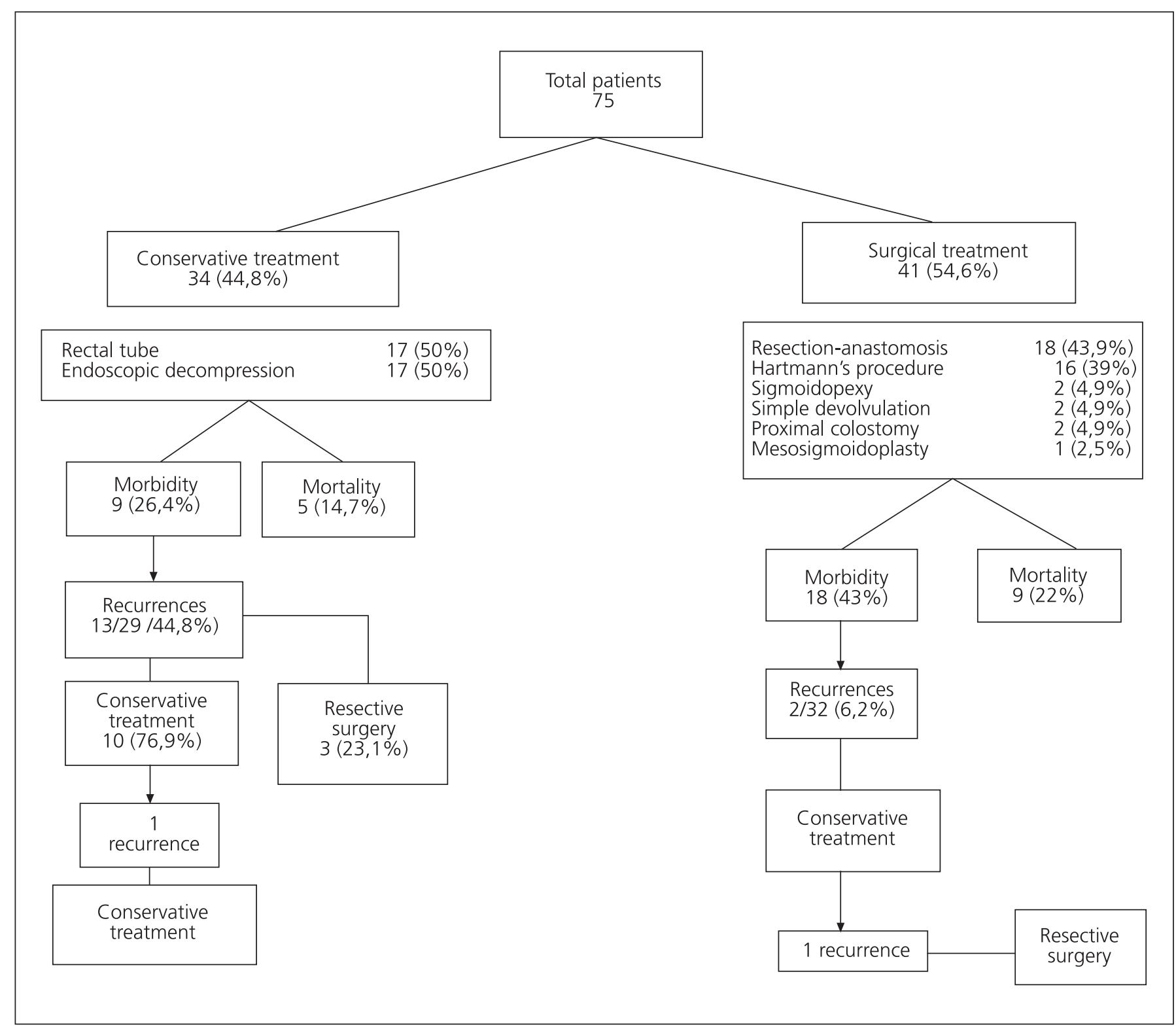

Fig. 1. Diagram of the procedures and evolution of our patients.

Diagrama-resumen de los procedimientos y evolución de nuestros pacientes.

\section{Table II. Severity scores}

\begin{tabular}{cccc}
\hline & $\begin{array}{c}\text { Emergency surgery } \\
(n=20)\end{array}$ & $\begin{array}{c}\text { Deferred surgery } \\
(n=21)\end{array}$ & p value \\
\hline ASA Score & & & \\
I & 0 & $2(9.5 \%)$ & \\
II & $8(40 \%)$ & $5(23.8 \%)$ & \\
III & $8(40 \%)$ & $10(47.6 \%)$ & \\
IV & $4(20 \%)$ & $4(19 \%)$ & \\
V & 0 & 0 & 0.107 \\
\hline P-Possum (SD) & $26.8(11.1)$ & $22.1(6.3)$ & \\
\hline SD: standard deviation. & & &
\end{tabular}

$13(44.8 \%)$ recurrences were registered, being the difference statistically significant when compared with the surgical group $(\mathrm{p}=0.005)$. The median (range) duration to first recurrence was of $3.5(0-41)$ months in the conservative group versus 94.5 (77-112) months in the surgery group.

In the recent years, a bigger number of decompressive colonoscopies were conducted than in previous years (45\% of cases in the period between 1990-1995 compared to $71.4 \%$ in $2003-2008$ ). There seems to be a trend in recent years towards resection with primary anastomosis, although there were no statistically significant differences when compared (Table V). 
Table III. Morbidity and mortality regarding the timing of surgery

\begin{tabular}{lcc}
\hline & $\begin{array}{c}\text { Emergency surgery } \\
n=20\end{array}$ & $\begin{array}{c}\text { Deferred surgery } \\
n=21\end{array}$ \\
\hline Morbidity & $9(45 \%)$ & $9(42.8 \%)$ \\
Suture dehiscence & $1(14 \%$ of anastomosis) & $2(18 \%$ of anastomosis $)$ \\
Postoperative ileus & - & 2 \\
Intrabdominal abscess & - & 1 \\
ARF & - & 1 \\
Cardiopulmonary & 3 & 2 \\
Sepsis & 2 & - \\
Evisceration & 1 & - \\
Postoperative hernia & 2 & 1 \\
Mortality & $6(30 \%)$ & $3(14.2 \%)$ \\
Multiorganic failure & 3 & 2 \\
Sepsis & 2 & - \\
Cardiopulmonary & 1 & 1 \\
\hline ARF: acute renal & &
\end{tabular}

ARF: acute renal failure.

\section{DISCUSSION}

It was Rokitansky $(3,12)$ who first defined in 1836 the colonic volvulus as an abnormal twisting of this intestinal portion on its mesenteric axis leading to an intestinal acute obstruction.

Sigmoid and cecal volvulus are the most common forms of these pathology, with a percentage of $60-70 \%$ and $20-30 \%$ of cases, respectively. Volvulus of the transverse and the splenic flexure of the colon represent less than $10 \%$ of intestinal volvulus $(3,12)$.

Epidemiologically, colonic volvulus is more prevalent in geographical regions of Africa, Eastern Europe, Asia, and South America, where it represents up to $50 \%$ of all cases of intestinal obstruction (13), differing from Western Europe and the United States where the incidence is much lower, about $5-10 \%$ of all intestinal obstructions (1). In countries with a high prevalence of volvulus, they usually appear in middle-aged men, whereas in Western countries the average age is around 70 years $(3,14)$, as in our series. Furthermore, physiological baseline status of these patients is usually quite poor, worsening when a bowel obstruction is present. The percentage of patients ASA III-IV in our series was over $70 \%$ with a mean pPossum value close to 25 .
Table IV. Overall morbidity and mortality

\begin{tabular}{lccc}
\hline & $\begin{array}{c}\text { Conservative treatment } \\
n=34\end{array}$ & $\begin{array}{c}\text { Surgical treatment } \\
n=41\end{array}$ & $p$ value \\
\hline Morbidity & $9(26.5)$ & $18(43.9)$ & 0.12 \\
Surgical wound infection & - & $5(27.7)$ & \\
Suture dehiscence & - & 3 (16\% of anastomosis) & \\
Evisceration & - & 1 & \\
Postoperative ileus & - & 2 & \\
Intrabdominal abscess & - & 1 & \\
ARF & 1 & 1 & \\
Cardiopulmonary & 1 & 5 & 0.17 \\
Meningitis & 1 & 0 & \\
Sepsis & 4 & 2 & \\
Multiorganic failure & 2 & 6 & \\
Postoperative hernia & - & 4 & \\
& & $9(21.9)$ & \\
Mortality & $5(14.7)$ & 6 & \\
Multiorganic failure & 2 & 1 & \\
Sepsis & 2 & & \\
Cardiopulmonary & 1 & & \\
The values are numbers with percentages between parenthesis. ARF: acute renal \\
failure.
\end{tabular}

Several factors have been associated with the appearance of colonic volvulus. The presence of a redundant and mobile sigmoid colon, with a narrow base of the mesenteric root, seems to be one of the major predisposing factors of this pathology. Similarly, an abnormal mobility of the cecal pole caused by an improper developmental fusion of the mesentery of the cecum and the ascending colon with the parietal peritoneum $(7,15,16)$ that facilitates the torsion of the colon. There are described in literature some other predisposing factors, such as a high-fiber diet, constipation, previous abdominal surgery, old age, pregnancy, diabetes, or neurological and psychiatric diseases such as dementia or schizophrenia $(3,5,14,17,18)$. Sigmoid volvulus has also been related to Hirschsprung's disease $(14,18)$ and megacolon from Chagas disease $(14,18)$, finding sometimes a neoplasm to be the cause of the volvulus. In our series, the largest one recorded in Spain, over $80 \%$ of patients referred chronic constipation, and over one third suffered from neurological or psychiatric diseases, presenting almost a quarter of them a history of previous abdominal surgery.

Diagnosis is based on clinical, radiological and endoscopic findings, being occasionally done intraoperatively.

Table V. Tendencies in emergency versus deferred surgery

\begin{tabular}{|c|c|c|c|c|}
\hline & \multicolumn{2}{|c|}{$\begin{array}{c}\text { Group } 1 \\
\text { (1990-1995) }\end{array}$} & \multicolumn{2}{|c|}{$\begin{array}{c}\text { Group } 2 \\
(2003-2008)\end{array}$} \\
\hline & $\begin{array}{l}\text { Emergency surgery } \\
\quad(n=7)\end{array}$ & $\begin{array}{l}\text { Deferred surgery } \\
\qquad(n=5)\end{array}$ & $\begin{array}{l}\text { Emergency surgery } \\
\qquad(n=6)\end{array}$ & $\begin{array}{l}\text { Deferred surgery } \\
\quad(n=11)\end{array}$ \\
\hline Resection & 4 & 5 & 5 & 11 \\
\hline Hartmann & 2 & 3 & 1 & 5 \\
\hline Anastomosis & 2 & 2 & 4 & 6 \\
\hline No resection & 3 & 0 & 1 & 0 \\
\hline
\end{tabular}


The clinical picture of intestinal obstruction, with vomiting, bloating, abdominal pain and constipation, along with abdominal X-ray, are the basic pillars in the diagnosis of this pathology. Abdominal radiograph usually shows distended small-bowel loops with fluid levels. The presence of the "coffee bean" sign is highly suggestive of colonic volvulus, and it is present in about $30 \%$ of cases (12).

Other tests used in diagnosis include barium enema, computed tomography (CT), magnetic resonance imaging (MRI) and endoscopic procedures, which can also be therapeutic achieving detorsion in many cases. The use of barium enema as a diagnostic and therapeutic method has been a controversial point, defending some authors that it only delays definitive surgical treatment of the volvulus $(3,12,19)$.

The treatment of colonic volvulus remains still controversial, depending the election of the procedure and the most appropriate therapeutic approach on the clinical status of the patient, the location of the problem, the suspicion or presence of peritonitis, bowel viability and on the experience of the surgical team.

In the presence of peritonitis or intestinal gangrene, emergent resection of the affected segment is the most appropriate surgical option, performing a primary anastomosis if both the patient's clinical condition and bowel ends are adequate. Resection with elaboration of a stoma (ileostomy or colostomy depending on the affected segment) is the recommended option in those cases of clinical instability of the patient, usually associated with severe peritonitis. Ören et al. (3), in a review of 827 cases of sigmoid volvulus, report a reduction in mortality when comparing cases of colonic volvulus that required urgent surgery and were treated by resection and primary anastomosis to cases operated under the same conditions who underwent a Hartmann's procedure or proximal stoma. Many other authors $(5,20)$ also support primary anastomosis in patients with intestinal gangrene but clinically stable.

In contrast, there are described in literature suture dehiscence rates close to $30 \%$, and increased mortality rate in the group of patients with gangrene or peritonitis who underwent primary anastomosis after resection (2). In our experience we have found a minor dehiscence rate for this type of surgery compared to the results reported by different authors. However, no significant differences in morbidity and mortality were found when comparing to the resection without anastomosis nor when comparing resective versus non-resective surgery. So, as long as patient's condition permits, we recommend performing resection and primary anastomosis in one time, decreasing this way the morbidity and mortality associated to two surgical procedures and the morbidity associated to the stoma.

Greater controversy exists in the management of colonic volvulus in the presence of a viable colon without clinical evidence of peritonitis. According to several studies, there seems to be general agreement in the use of decompressive colonoscopy as an initial treatment for colonic volvulus, with or without insertion of a rectal tube. Colonoscopy, besides being a therapeutic measure, it allows the evaluation of the colonic mucosa and therefore the presence or absence of signs of ischemia (21), being effective in more than $70 \%$ of patients $(12,22)$. In case of failure of endoscopic decompression, which happens in most cases of volvulus of the cecum (23), surgery may be necessary.

If detorsion is effective, the current tendency is the indication of a deferred surgery in the coming days to detorsion, given the high rates or recurrence of the volvulus if only nonsurgical measures are applied. Several studies have shown recurrence rates up to $90 \%$ following a successful nonsurgical detorsion. Grossman et al. (9) observed a mortality rate of $6 \%$ for elective surgery after decompressive colonoscopy in sigmoid volvulus. In contrast, for those cases treated only by colonoscopic detorsion they observed a mortality rate of $12 \%$, recurrence rate of $23 \%$ and a mortality rate associated to the recurrence episode of $20 \%$, so they recommend surgery as a definitive treatment for colonic volvulus. In our series, we have recorded a high rate of recurrences after conservative treatment which occurs more precociously that recurrences recorded after surgical treatment.

Cecopexy and cecostomy are part of the non-resective surgical options in the treatment of colonic volvulus, but when compared to previously exposed resective treatment, worst results in terms of mortality, which represents up to $40 \%$ (7), were found. This is probably due to the fact that they are used in patients with high surgical risk. However, these two procedures prevent recurrences in some cases and could be options to have in mind in high risk and clinically unstable patients.

Currently, laparoscopic approach is a valid option in the treatment of this pathology, with good results according to different published series $(24,25)$, improving hospital stay, postoperative pain and the morbidity associated to this surgery, specially abdominal wall problems.

In conclusion, colonic volvulus are, in our country, a disease of elderly people with considerable comorbidity, so its diagnostic and therapeutic management must be performed by a multidisciplinary and specialized team, being the resection with primary anastomosis a safe method in patients with appropriate clinical conditions and after a successful endoscopic decompression with no signs of intestinal ischemia or peritonitis.

\section{REFERENCES}

1. Chang JG, Shelton A, Welton ML. Volvulus. En: Dogherty GM, Way LW, editors. Surgical diagnosis and treatment. 10th ed. Connecticut: Appleton and Lance; 1994. p. 675-7.

2. Akcan A, Akyildiz H, Artis T. Feasibility of single-stage resection and primary anastomosis in patients with acute noncomplicated sigmoid volvulus. Am J Surg 2007; 193: 421-6. 
3. Ören D, Selçuk S, Aydinli B, Yidirgan MI, Basoglu M, Polat KY, et al. An algorithm for the management of sigmoid colon volvulus and the safety of primary resection: Experience with 827 cases. Dis Colon Rectum 2007; 50: 489-97.

4. Arnold GJ, Nance FC. Volvulus of the sigmoid colon. Ann Surg 1973; 177: 527-37.

5. Kuzu M, Aslar A, Soran A, Polat A, Topcu O, Hengirmen S. Emergent resection for acute sigmoid volvulus: results of 106 consecutive cases. Dis Colon Rectum 2002; 45: 1085-90.

6. Dulger M, Canturk NZ, Utkan NZ, Gonullu NN. Management of sigmoid colon volvulus. Hepatogastroenterology 2000; 47: 1280-3.

7. Madiba TE, Thomson SR. The management of cecal volvulus. Dis Colon Rectum 2002; 45: 264-7.

8. Ballantyne GH, Bradner MD, Beart RW, Illstrup DM. Volvulus of the colon. Incidence and mortality. Ann Surg 1985; 202: 83-92.

9. Grossmann E, Longo W, Stratton M. Sigmoid volvulus in department of veterans affairs medical centers. Dis Colon Rectum 2000; 43: 414-8

10. Uribe N, García-Granero E, Ruiz del Castillo J, Campos JC, Calvete J, Alós R, et al. Vólvulos de colon. Revisión de 28 casos. Cir Esp 1990; 47: 548-54.

11. Echenique M, Amondaraín JA. Vólvulos del intestino grueso. Rev Esp Enferm Dig 2002; 94: 201-5.

12. Scott C, Trotta B, Dubose J. A cruel twist: post-operative cecal volvulus. Turkish J Trauma \& Emerg Surg 2008; 14: 158-62.

13. Bagarani M, Conde A, Longo R. Sigmoid volvulus in West Africa: a prospective study on surgical treatments. Dis Colon Rectum 1993; 36: $186-90$

14. Safioleas M, Chatziconstantinou C. Clinical considerations and therapeutic strategy for sigmoid volvulus in the elderly: a study of 33 cases. World J Gastroenterol 2007; 13: 921-4.
15. Burke JB, Ballantyne GH. Cecal volvulus: low mortality at a city hospital. Dis Colon Rectum 1984; 27: 737-40.

16. Rabinovici R, Simansky DA, Kaplan O, Mavor E, Manny J. Cecal volvulus. Dis Colon Rectum 1990; 33: 765-9.

17. Northeast AD, Dennison AR, Lee EG. Sigmoid volulus: new thoughts on the epidemiology. Dis Colon Rectum 1984; 27: 260 -

18. Lledó S, García-Armengol J. Estreñimiento, vólvulos y pseudoobstrucción. En: Parrilla P, Jaurrieta J, Moreno M. Cirugía AEC. Manual de la Asociación Española de Cirujanos. Madrid: Editorial Médica Panamericana; 2005. p. 390-6.

19. Bhatnagar BNS, Sharma CL. Nonresective alternative for the cure of nongangrenous sigmoid volvulus. Dis Colon Rectum 1998; 41: 381 8

20. Raveenthiran V. Restorative resection of unprepared left-colon in gangrenous vs. viable sigmoid volvulus. Int J Colorectal Dis 2004 19: 258-63.

21. Turan M, Sen M, Karadayi K, Koyuncu A, Topcu O, Yildirir C, et al. Our sigmoid colon volvulus experience and benefits of colonoscope in detorsion process. Rev Esp Enferm Dig 2004; 96: 32-5.

22. Martínez Ares D, Yánez López J, Souto Ruzo J, Vázquez Millán MA, González Conde B, Suárez López F, et al. Indication and results of endoscopic management of sigmoid volvulus. Rev Enferm Dig 2003; 95: 544-8.

23. Anderson JR, Welch GH. Acute volvulus of the right colon. An analysis of 69 patients. World J Surg 1986; 10: 336-42.

24. Cartwright-Terry T, Phillips S, Greenslade GL, Dixon AL. Laparoscopy in the management of closed loop sigmoid volvulus. Colorectal Dis 2008; 10: 370-2.

25. Kelly M, Bunni J, Pullyblank A. Laparoscopic assisted right hemicolectomy for caecal volvulus. World J Emerg Surg 2008; 3: 4.

\title{
Manejo del vólvulo de colon. Experiencia en 75 pacientes
}

\author{
C. Mulas, M. Bruna, J. García-Armengol y J. V. Roig \\ Servicio de Cirugía General y del Aparato Digestivo. Consorcio Hospital General Universitario de Valencia
}

\section{RESUMEN}

Introducción: el manejo diagnóstico-terapéutico del vólvulo de colon continúa siendo un tema controvertido en la actualidad. En base a la situación clínica del paciente, a la experiencia de un equipo multidisciplinar, deben elegirse el tipo de cirugía, momento de su realización y el empleo de otras opciones descompresivas.

Objetivos: los objetivos del presente trabajo son revisar nuestra experiencia y resultados en el tratamiento de los pacientes con vólvulo de colon.

Material y métodos: hemos realizado un estudio retrospectivo descriptivo de los pacientes diagnosticados de vólvulo de colon entre enero de 1990 y septiembre de 2008 en nuestro centro.

Resultados: se han incluido un total de 75 pacientes, de edad media 72,7 años y, en su mayoría, con comorbilidades asociadas y estreñimiento. La zona de volvulación más frecuentemente im- plicada fue el sigma $(85,3 \%)$. La sonda rectal fue utilizada como única medida terapéutica en 17 pacientes (22,4\%), el tratamiento endoscópico en otros 17 (22,4\%), y la cirugía en 41 (55,2\%). La resección intestinal con anastomosis primaria fue la opción quirúrgica más empleada. La morbilidad postoperatoria fue del $43 \%$, siendo las infecciones de herida la complicación más frecuente. En el grupo de tratamiento no quirúrgico la morbilidad fue del $26,4 \%$, aunque con una mayor y más precoz tasa de recidivas.

Conclusiones: el vólvulo de colon presenta una elevada tasa de morbimortalidad asociada, debiendo realizarse su tratamiento de forma individualizada. La cirugía resectiva con anastomosis primaria en pacientes clínicamente estables es la opción terapéutica definitiva más adecuada y con menores tasas de recidiva.

Palabras clave: Vólvulo de colon. Oclusión intestinal. Descompresión endoscópica. Tratamiento quirúrgico. 


\section{INTRODUCCIÓN}

El vólvulo de colon se describe como la torsión del intestino grueso sobre su eje mesentérico, ocasionando así un cuadro de oclusión intestinal. Representa en nuestro medio entre el 5-10\% de los cuadros de oclusión intestinal baja (1).

El diagnóstico temprano y correcto de esta patología típica de pacientes añosos y encamados es fundamental para conseguir un tratamiento adecuado, encaminado a corregir las alteraciones hidroelectrolíticas y nutricionales que se producen y restaurar el tránsito intestinal, solucionando el problema mecánico que ocasiona la volvulación $(2,3)$.

En la actualidad existen discrepancias en cuanto al tratamiento de los pacientes con un vólvulo de colon. Por una parte, parece evidente que en los que presentan un cuadro de abdomen agudo, perforación intestinal o necrosis isquémica de la mucosa intestinal, la cirugía resectiva urgente es el tratamiento indicado (2-8). Por otra, el manejo inicial de los estables clínicamente y estado general conservado mediante devolvulación y descompresión endoscópica es aceptado en muchos centros como primera opción terapéutica. La controversia aparece a la hora de decidir el tipo de tratamiento definitivo en cada caso y la estrategia y técnica quirúrgica más apropiada $(4,9)$.

Hay escasa bibliografía nacional y series cortas sobre este tema $(10,11)$, por lo que nos hemos planteado como objetivos del presente trabajo revisar nuestra experiencia y resultados en el tratamiento de los pacientes con vólvulo de colon.

\section{MATERIAL Y MÉTODOS}

Hemos realizado un estudio retrospectivo y descriptivo de los casos diagnosticados y tratados de vólvulo de colon en nuestro centro desde enero de 1990 hasta septiembre de 2008 confeccionando una base de datos. Mediante la revisión detallada de las historias clínicas de los pacientes se han recogido parámetros epidemiológicos así como la forma de presentación, exploración física y los diferentes medios diagnósticos-terapéuticos empleados en su manejo, incluyendo pruebas de imagen diagnósticas, puntuación ASA, Possum-fisiológico, hallazgos intraoperatorios y la técnica quirúrgica o procedimiento endoscópico empleado en cada caso. También hemos analizado la evolución clínica del episodio, morbimortalidad asociada a cada técnica, su efectividad clínica y porcentaje de recidivas.

Para el procesamiento de los datos se empleó el programa informático SPSS ${ }^{\circledR}$ versión 15.0 para Windows ${ }^{\circledR}$. (SPSS Inc., Chicago IL, USA). Se usaron los tests de Chi cuadrado y test exacto de Fisher según indicado, para el estudio de proporciones. Para las variables muestrales con una distribución normal se han usado la media y la desviación estándar como medidas de centralización y dispersión y para aquellas que no siguen una distribución normal, la mediana y el rango. Se consideró un valor de $\mathrm{p}$ $<0,05$ como estadísticamente significativo.

\section{RESULTADOS}

Se han incluido un total de 75 pacientes de edad media (DS) de 72,7 (16) años. Sus características, antecedentes personales y datos clínicos se describen en la tabla I.

La zona de volvulación más frecuentemente implicada fue el sigma en 64 pacientes $(85,3 \%)$, siendo mucho más infrecuentes las volvulaciones de ciego, con 10 casos $(13,3 \%)$. Un único paciente presentó un vólvulo a nivel de colon transverso.

La presentación clínica fue variable, aunque la mayor parte acudió por un cuadro de oclusión intestinal, siendo la mediana (rango) de tiempo de evolución de 3 (0-30) días y la mediana (rango) de días sin defecar de 2 (0-10).

Entre las pruebas diagnósticas, se utilizó la radiografía simple de abdomen en 72 casos (96\%), el enema opaco en $27(36 \%)$, la tomografía computerizada (TC) abdominopélvica en $8(10,6 \%)$, y la endoscopia en 43 casos $(57,3 \%)$.

Todos los pacientes fueron tratados médicamente mediante dieta absoluta, hidratación intravenosa y analgesia. Los procedimientos empleados para el manejo específico de la volvulación fueron: la descompresión mediante sonda rectal, la descompresión endoscópica y la cirugía. La figura 1 muestra un diagrama resumen de los diferentes procedimientos empleados y la evolución de nuestros pacientes. De los 41 tratados quirúrgicamente, a 9 se les había colocado previamente una sonda rectal y a 7 se les practicó una endoscopia antes de la intervención. Todos los pacientes con vólvulo de ciego fueron intervenidos quirúrgicamente, excepto uno, en quien, por su mal estado general, se decidió intentar su devolvulación endoscópica sin éxito, falleciendo por fracaso multiorgánico.

Tabla I. Características clínicas de los pacientes

\begin{tabular}{lclc}
\hline Caracteristicas & $n(\%)$ & Características & $n(\%)$ \\
\hline Sexo & & Síntomas y exploración \\
$\quad$ Varones & $43(56,6)$ & Vómitos & $33(44)$ \\
$\quad$ Mujeres & $32(42,7)$ & Distensión abdominal & $73(97,3)$ \\
Comorbilidad & & Dolor cólico & $66(88)$ \\
$\quad$ Diabetes & $15(19,7)$ & Dolor continuo & $7(9,3)$ \\
EPOC & $9(11,8)$ & Peritonismo & $5(6,6)$ \\
Patología cardiaca & $28(37,3)$ & Clasificación ASA $(n=73)$ & \\
Patología neurológica & $26(35,5)$ & I & $2(2,7)$ \\
Patología psiquiátrica & $21(28,9)$ & $\|$ & $19(24)$ \\
Cirugía abdominal previa & $18(23,7)$ & $\|$ & $33(46,7)$ \\
Ritmo defecatorio habitual $(n=71)$ & IV & $14(20)$ \\
$\quad$ Normal & $6(8,4)$ & Possum fisiológico medio (DS) & $24,7(9)$ \\
Estreñimiento & $60(84,5)$ & & \\
Diarrea & $5(7,1)$ & & \\
\hline
\end{tabular}

DS: desviación estándar. 
La cirugía se realizó de forma urgente en 20 de los 41 casos $(48,8 \%)$, de forma diferida en el mismo ingreso en $17(41,4 \%)$, y programada en un ingreso diferente al del episodio de volvulación en 4 casos $(9,8 \%)$, siendo la mediana (rango) de días desde el diagnóstico hasta la cirugía de 4,5 (0-170) días. No se encontraron diferencias significativas en cuanto a clasificación ASA y Possum entre dichos grupos de pacientes (Tabla II). En la tabla III se muestran los resultados comparativos en términos de morbimortalidad entre la cirugía urgente y la cirugía diferida.

\begin{tabular}{cccc}
\multicolumn{4}{c}{ Tabla II. Clasificación ASA y Possum en cirugía urgente } \\
frente a cirugía diferida
\end{tabular}

La cirugía resectiva fue la opción quirúrgica más empleada, encontrando diferencias estadísticamente significativas entre los pacientes intervenidos de forma diferida y urgente $(95,2$ frente a $70, p=0.036)$. Sin embargo no se encontraron diferencias significativas al comparar el tipo de cirugía resectiva realizada (resección con anastomosis primaria frente al procedimiento de Hartmann). La descompresión endoscópica permitió diferir la cirugía y mejorar el estado basal del paciente en 4 de los 7 casos en los que se empleó como medida previa a la cirugía.

Se preparó el colon para la cirugía en 15 de los pacientes intervenidos $(36,5 \%)$, no realizando en ningún caso lavado intraoperatorio. Durante el acto quirúrgico, se evidenciaron signos de isquemia de colon en 6 pacientes (7,9\% del total y $14,6 \%$ de los operados). Esta incidencia fue mayor en los pacientes intervenidos de forma urgente ( 25 frente a $4,8 \%, \mathrm{p}=0,072$ ).

Se registraron complicaciones en 18 de los 41 pacientes operados $(43,9 \%)$, que se muestran en la tabla III. No hubo diferencias estadísticamente significativas en la morbilidad de los pacientes resecados $(14 / 34 ; 41,1 \%)$ frente a la de los no resecados $(4 / 7 ; 57,1 \%) ; \mathrm{p}=0,21$. El procedimiento de Hartmann (resección intestinal más colostomía derivativa) se asoció a una morbilidad postoperatoria del 50\% (8 de 16), mientras que en los pacientes con anastomosis primaria esta fue del 33,3\% (6 de 18; $p=0,17$. La estancia hospitalaria media (DS) fue de 16,2 (10) días, registrándose durante el seguimiento posterior 2 casos $(6,2 \%)$ de recidiva del vólvulo, a los 6 y 10 años tras la cirugía.
Tabla III. Cirugía urgente frente a cirugía diferida

\begin{tabular}{lcc}
\hline & $\begin{array}{c}\text { Cirugía urgente } \\
n=20\end{array}$ & $\begin{array}{c}\text { Cirugía diferida } \\
n=21\end{array}$ \\
\hline Morbilidad & $9(45 \%)$ & 9 (42.8\%) \\
Dehiscencia de sutura & 1 (14\% de las anastomosis) & 2 \\
Illeo mantenido & - & (18\% de las anastomosis) \\
Absceso intraabdominal & - & 2 \\
IRA & - & 1 \\
Cardiopulmonares & 3 & 1 \\
Sepsis & 2 & 2 \\
Evisceración & 1 & - \\
Eventración & 2 & - \\
& & 1 \\
Mortalidad & $6(30 \%)$ & $3(14.2 \%)$ \\
Fallo multiorgánico & 3 & 2 \\
Sepsis & 2 & - \\
Cardiopulmonares & 1 & 1 \\
\hline
\end{tabular}

De los $34(45,3 \%)$ pacientes del grupo global que fueron tratados de forma conservadora, se registraron complicaciones en $9(26,4 \%)$ (Tabla IV). La comorbilidad asociada a este grupo fue mayor que la del grupo tratado quirúrgicamente, presentando casi el $40 \%$ de los pacientes asociación de patología cardiorrespiratoria y sistémica frente al 9,5\% del grupo quirúrgico $(p=0,016)$. La estancia hospitalaria media (DS) de este grupo fue de 8,1 (8) días. Durante el seguimiento se registraron 13 recidivas $(44,8 \%)$, estadísticamente más frecuentes que en el grupo tratado quirúrgicamente $(\mathrm{p}=0,005)$, siendo la mediana (rango) de tiempo transcurrido hasta la primera recidiva de 3,5 (0-41) meses frente a 94,5 (77-112) meses en el grupo de cirugía.

Se utilizó el TC como prueba complementaria en un mayor porcentaje de pacientes en el periodo de tiempo.

Tabla IV. Morbimortalidad y sus causas

\begin{tabular}{lccc}
\hline & $\begin{array}{c}\text { Tratamiento conservador } \\
n=34\end{array}$ & $\begin{array}{c}\text { Tratamiento quirúrgico } \\
n=41\end{array}$ & Valor de p \\
\hline Morbilidad & $9(26,5)$ & $18(43,9)$ & 0,12 \\
Infección de herida quirúrgica & - & $5(27,7)$ & \\
Dehiscencia de sutura & - & $3(16 \%$ de las anastomosis $)$ & \\
Evisceración & - & 1 & \\
Ileo mantenido & - & 2 & \\
Absceso intraabdominal & - & 1 & \\
Insuficiencia renal aguda & 1 & 1 & \\
Cardiopulmonares & 1 & 5 & \\
Meningitis & 1 & 0 & \\
Sepsis & 4 & 2 & 0,17 \\
Fallo multiorgánico & 2 & 6 & \\
Eventración & - & 4 & \\
& & $9(21,9)$ & \\
Mortalidad & $5(14,7)$ & 6 & \\
Fallo multiorgánico & 2 & 2 & \\
Sepsis & 2 & 1 & \\
Cardiopulmonares & 1 & & \\
\hline
\end{tabular}

Los valores son números, con porcentajes entre paréntesis. 
Se realizó un mayor número de endoscopias descompresivas en los últimos años ( $45 \%$ de los casos en el periodo entre 1990-1995 frente a un 71,4\% en 2003-2008). Parece existir una tendencia en los últimos años hacia la resección con anastomosis primaria aunque no se encontraron diferencias estadísticamente significativas (Tabla V).

\section{DISCUSIÓN}

Fue Rokitansky $(3,12)$ quien por primera vez definió en 1836 el vólvulo de colon como una torsión anómala de esta porción intestinal sobre su eje mesentérico, provocándose así un cuadro de oclusión intestinal en asa cerrada.

El vólvulo de sigma y el de ciego representan las formas más frecuentes, con un porcentaje del $60-70 \%$ y del 20-30\% de los casos respectivamente. Los de colon transverso y ángulo esplénico representan menos del $10 \%$ de vólvulos intestinales $(3,12)$.

Epidemiológicamente, existe una mayor incidencia en regiones geográficas de África, India, Europa del Este, Asia y Sudamérica, donde llegan a suponer hasta el 50\% de todas las causas de obstrucción intestinal (13), a diferencia de lo que ocurre en Europa Occidental y Estados Unidos, donde la incidencia es mucho menor, alrededor del $5-10 \%$ de todas las oclusiones (1). En aquellos países con una prevalencia elevada de vólvulos, estos suelen desarrollarse en varones de mediana edad, mientras que en los países occidentales la edad media ronda los 70 años $(3,14)$, como en nuestra serie. Además, el estado general y fisiológico de estos pacientes está bastante deteriorado basalmente, lo que se agudiza al presentar un cuadro de obstrucción intestinal, con un porcentaje de pacientes ASA III-V de más del $70 \%$ en nuestra serie y con un valor de Possum fisiológico medio, cercano a 25.

Son varios los factores que se han relacionado con la aparición de volvulaciones de colon. La presencia de un sigma edundante y móvil, con una estrecha fijación mesentérica parece ser uno de los principales predisponentes para la aparición de esta patología. De la misma forma, una movilidad anormal del polo cecal ocasionada por una incorrecta fijación del mesenterio del ciego y del colon ascendente facilita la torsión del mismo $(7,15,16)$. Se han descrito en la bibliografía otra serie de factores que facilitan la aparición de vólvulos cólicos, como una dieta rica en fibra, el estreñimiento grave, la cirugía abdominal previa, edad avanzada, el embarazo, la diabetes, o enfermedades neurológicas y psiquiátricas como la demencia y la esquizofrenia $(3,5,14,17,18)$. El vólvulo de sigma se ha relacionado también con la enfermedad de Hirschsprung $(14,18)$ y el megacolon de la enfermedad de Chagas $(14,18)$, siendo en ocasiones una neoplasia la causante de la volvulación. En nuestra serie, la más amplia registrada en España, más del $80 \%$ de pacientes referían estreñimiento crónico, y más de un tercio padecían enfermedades neurológicas o psiquiátricas, presentando casi un cuarto de ellos un antecedente de cirugía abdominal previa.

El diagnóstico del vólvulo se establece normalmente en base a los hallazgos clínicos, radiológicos y endoscópicos, siendo ocasionalmente diagnosticado de forma intraoperatoria. El cuadro clínico de obstrucción intestinal, con vómitos, distensión, dolor abdominal y disminución de la expulsión de heces y gases, junto con una radiografía de abdomen, constituyen los pilares básicos en la sospecha diagnóstica de esta patología. La radiografía muestra generalmente una dilatación de asas de intestino grueso con niveles hidroaéreos, siendo el hallazgo de una imagen en "grano de café" muy sugestivo de volvulación intestinal. Este patrón radiológico suele estar presente en alrededor de un $30 \%$ de los casos (12).

Otras pruebas empleadas en el diagnóstico son el enema opaco, tomografía computerizada (TC), resonancia magnética $(\mathrm{RM})$ y los procedimientos endoscópicos, que además pueden ser terapéuticos al conseguir la devolvulación en muchos de los casos. El uso del enema opaco como método diagnóstico-terapéutico ha sido debatido, argumentando en ciertas publicaciones que lo único que aporta es un retraso en el tratamiento quirúrgico definitivo del vólvulo $(3,12,19)$.

El tratamiento del vólvulo de colon sigue siendo un tema controvertido en la actualidad, dependiendo la elección del procedimiento y la actitud terapéutica más adecuada del estado clínico del paciente, la localización de la lesión, la sospecha o presencia de peritonismo, la viabili-

Tabla V. Tendencias en cirugía urgente frente a cirugía diferida

\begin{tabular}{ccccc}
\hline & $\begin{array}{c}\text { Grupo } 1 \\
(1990-1995)\end{array}$ & $\begin{array}{c}\text { Grupo } 2 \\
(2003-2008)\end{array}$ \\
\hline & $\begin{array}{c}\text { Cirugía urgente } \\
(n=7)\end{array}$ & $\begin{array}{c}\text { Cirugía diferida } \\
(n=5)\end{array}$ & $\begin{array}{c}\text { Cirugía urgente } \\
(n=6)\end{array}$ & $\begin{array}{c}\text { Cirugía diferida } \\
(n=11)\end{array}$ \\
\hline Resección & 4 & 5 & 5 & 11 \\
Hartmann & 2 & 3 & 1 & 5 \\
Anastomosis & 2 & 2 & 4 & 6 \\
No resección & 3 & 0 & 1 & 0 \\
\hline
\end{tabular}

$p>0,05$ en todas las comparaciones de cirugías entre los 2 grupos. 
dad del intestino afecto y la experiencia del equipo quirúrgico.

En presencia de peritonitis o gangrena intestinal, la resección del segmento afecto de forma urgente es la técnica quirúrgica más adecuada, realizando una anastomosis primaria siempre y cuando la situación clínica del paciente sea estable y las condiciones del intestino las adecuadas. La resección sin anastomosis con elaboración de una ostomía proximal (ileostomía o colostomía según la porción cólica afecta) es la opción recomendada en aquellos casos de inestabilidad clínica del paciente, generalmente asociada a peritonitis grave. Ören y cols. (3), en una revisión de 827 casos de vólvulos de sigma, objetivaron una reducción en la tasa de mortalidad cuando compararon los casos de volvulación intestinal que requirieron intervención de urgencia y fueron tratados mediante resección y anastomosis primaria frente a los casos intervenidos en las mismas condiciones a los que se les realizó una intervención de Hartmann o estoma proximal. Otros muchos autores $(5,20)$, apoyan también la anastomosis primaria en aquellos pacientes con gangrena intestinal y clínicamente estables.

En contraposición, en la literatura se describen tasas de dehiscencia de sutura cercanas al $30 \%$, así como un aumento de mortalidad en el grupo de pacientes con gangrena o peritonitis que fueron sometidos a anastomosis primaria tras resección (2). En nuestra experiencia hemos encontrado una tasa de dehiscencia menor para este tipo de cirugía en comparación con los resultados expuestos por diferentes grupos. Sin embargo, no existen diferencias significativas de morbimortalidad con respecto al grupo de resección sin anastomosis, ni cuando comparamos la cirugía resectiva frente a la no resectiva. Por tanto, siempre que las condiciones del paciente lo permitan, recomendamos la realización de la resección en un tiempo con anastomosis primaria, lo que permite reducir así la morbimortalidad que conlleva someter al paciente a dos procesos quirúrgicos, así como la morbilidad asociada al estoma.

Mayor controversia existe en el manejo del vólvulo intestinal en presencia de un colon viable y sin datos clínicos de peritonismo. Según diversos estudios, parece existir un acuerdo general en el uso de la colonoscopia descompresiva como tratamiento inicial del vólvulo de colon, con o sin inserción de sonda rectal. La colonoscopia, además de ser una medida terapéutica, permite evaluar el estado de la mucosa cólica y por tanto la presencia o no de gangrena o signos de isquemia (21), mostrándose efectiva en más de un $70 \%$ de los pacientes $(12,22)$. En caso de fallo en la descompresión endoscópica, lo cual suele ocurrir en la mayoría de los casos de vólvulo de ciego (23), será necesaria una cirugía resolutiva.

Si la detorsión es efectiva, la tendencia actual es la indicación de una cirugía diferida en los próximos días a la detorsión, dadas las altas tasas de recurrencia del vólvulo intestinal si sólo se aplican medidas no quirúrgicas. Diversos estudios han demostrado tasas de recurrencia de hasta el $90 \%$ tras una detorsión efectiva por medidas no quirúrgicas. Grossman y cols. (9) observaron una tasa de mortalidad del $6 \%$ para la cirugía electiva tras una colonoscopia descompresiva en vólvulos de sigma, encontrando en contraposición, para la descompresión por colonoscopia seguida únicamente de observación una tasa de mortalidad del $12 \%$, recurrencia del $23 \%$ y mortalidad asociada a dicha recurrencia del $20 \%$, por lo que recomiendan la cirugía como tratamiento definitivo del vólvulo de colon. En nuestra serie, hemos registrado una elevada tasa de recidivas tras el tratamiento conservador y además se producen más precozmente con respecto a las que acontecen tras el tratamiento quirúrgico.

La cecopexia y la cecostomía forman parte de las opciones de tratamiento quirúrgico no resectivo del vólvulo de colon, pero al compararlos con la resección intestinal previamente expuesta, han mostrado peores resultados en cuanto a mortalidad, que llega a ser del $40 \%$ (7), probablemente porque se emplean en pacientes con elevado riesgo quirúrgico. Sin embargo, estos dos procedimientos previenen la recurrencia en ciertos casos y podrían ser opciones a plantear ante pacientes de alto riesgo e inestables clínicamente.

Actualmente, el abordaje laparoscópico es una opción más en el tratamiento de este tipo de patología, con resultados óptimos según las diferentes series publicadas $(24,25)$, mejorando la estancia, el dolor postoperatorio y la morbilidad asociada a esta cirugía, sobre todo la relacionada con los problemas de la pared abdominal.

En conclusión, los vólvulos de colon son, en nuestro medio, una patología de pacientes añosos con considerable comorbilidad, por lo que su manejo diagnóstico-terapéutico debe realizarse por un equipo multidisciplinar y especializado, resultando la resección con anastomosis primaria un método seguro en pacientes con condiciones clínicas adecuadas y tras una descompresión endoscópica en casos de ausencia de peritonitis o signos de isquemia intestinal. 